\title{
ВПЛИВ ІННОВАЦІЙНИХ ТЕХНОЛОГІЙ НА РОЗВИТОК ТОРГІВЛІ
}

\section{THE INFLUENCE OF INNOVATIVE TECHNOLOGIES ON TRADE DEVELOPMENT}

\author{
Шевченко Катерина Вікторівна \\ студентка, \\ Сумський державний університет \\ ORCID: https://orcid.org/0000-0003-4558-7792 \\ Сагер Людмила Юріївна \\ кандидат економічних наук, доцент, \\ Сумський державний університет \\ ORCID: https://orcid.org/0000-0002-5628-5477
Shevchenko Kateryna, Saher Liudmyla
Sumy State University

\begin{abstract}
Метою статті є оцінювання впливу інновацій на розвиток торгівлі, а також визначення трендів розвитку фрізичної торгівлі. У статті представлена статистика розвитку електронної, роздрібної та оптової торгівлі. Також наявні приклади торгово-технологічних інновацій та їх вплив на роздрібну торгівлю. Розглянуто приклади та наведено їх переваги і ризики у використанні як для покупців, так і для торговельних підприємств. Було оцінено майбутнє роздрібної торгівлі та представлені тренди офрлайн-точок. Доповнена реальність, роботи, електронні цінники, надолонні каси, технологія NFC та концепція SoLoMo, служби доставки, трансформація супермаркетів - це майбутнє, яке вже тут. Результатом дослідження стало визначення того, що автоматизація та зростання штучного інтелекту змінюють торгові потоки та визначальними факторами стають кваліфікація робочої сили, якість інфрраструктури та доступ до ресурсів.
\end{abstract}

Ключові слова: інновація, переваги, покупці, підприємство, офлайн-точки, тренди.

Целью статьи является оценка влияния инноваций на развитие торговли, а также определение трендов офлайн-точек. В статье представлена статистика развития электронной, розничной и оптовой торговли. Также есть примеры торгово-технологических инноваций и их влияние на розничную торговлю. Рассмотрены примеры и приведены их преимущества и риски в использовании как для покупателей, так и для торговых предприятий. Было оценено будущее розничной торговли и представлены тренды офрфлайн-точек. Дополненная реальность, работы, электронные ценники, кассы, технология NFC и концепция SoLoMo, службы доставки, транссормация супермаркетов - это будущее, которое уже здесь. Результатом исследования стало определение того, что автоматизация и рост искусственного интеллекта изменяют торговые потоки и определяющими фракторами становятся квалификация рабочей силы, качество инфраструктуры и доступ к ресурсам.

Ключевые слова: инновация, предпочтения, покупатели, предприятие, офлайн-точки, тренды.

The purpose of the article is to assess the impact of innovation on the development of trade and identify trends in offline outlets. The history of trade reflects a continuous march of technological innovation. The article argues that trade enters a new section, where information and data flows are decisive, as well as technological changes that change the industry's value chains. Trade flows are shaped by many forces (including trade policy), changes in the nature and location of consumer demand, and differences in the cost of labor and other resources depending on the geographical region. Another critical but underestimated driver of trade flows is technology. Advanced trade technologies and marketing, various information, technical, and technological innovation development projects, which radically change the traditional idea of trade business, are actively entering the trade industry. The focus is on innovation. The future of world trade will be driven primarily by Internet-related innovations, including the Internet of Things, artificial intelligence, 3D printing, and blockchain technology. The article presents statistics on the development of electronic, retail, and wholesale trade. There are also examples of trade and technological innovations and their impact on retail. Examples are considered, and their advantages and risks in use both for buyers and the trading enterprises are resulted. The future of retail trade was assessed, and trends of offline outlets were presented. 
Augmented reality, robots, electronic price tags, cash registers, NFC technology, and the SoLoMo concept, delivery services, supermarket transformation - this is the future that is already here. The result of the study was that automation and the growth of artificial intelligence are changing trade flows. The determining factors are the workforce's skills, the quality of infrastructure, and access to resources. The authors identify the benefits and risks of each innovation, present their potential impact. These innovations require significant funds for their implementation, especially for robots, electronic price tags, and SmartCart. Also, the older generation is not yet ready for the SoLoMo concept, as most of them do not use smartphones and do not have access to the Internet. Another risk to pay attention to is high-cost repairs in case of technology failure. However, these technologies are being introduced rapidly, and outlets are trying to reduce these risks.

Keywords: innovation, advantages, buyers, enterprise, offline points, trends.

Постановка проблеми. В сучасних умовах здійснення комерційної діяльності важливим аспектом $€$ забезпечення ефективності методів реалізації та просування продукції, зважаючи на насиченість ринку, на постійно зростаючий рівень конкуренції та/або зміну потреб та запитів споживачів і їхньої купівельної спроможності. Саме вибір есрективних підходів дозволяє забезпечувати відповідний обсяг збуту, величину прибутку, зберігати чи нарощувати частку ринку і т.д. При цьому впровадження інновацій, які $€$ потужним механізмом економічного розвитку, підвищення якості товарів й забезпечення конкурентоспроможності усіх галузей національної економіки, у тому числі й сорери торгівлі, дозволяє підприємствам збільшувати рівень конкурентоспроможності за рахунок більш якісного задоволення потреб споживачів. Розвиток технологій у всьому світі сприяє розвитку торговельно-технологічних інновацій у цій сорері. Відповідно дослідження змісту та характеру впливу інноваційних технологій на розвиток торгівельних підприємств є своєчасним; може становити підґрунтя для подальших досліджень у визначенні особливостей застосування інноваційних технологій та їхнього впливу на поведінку споживачів у торгових залах 3 перспективою подальшого впровадження результатів наукових досліджень у практику діяльності вітчизняних підприємств торгівлі.

Аналіз останніх досліджень та публікацій. Дослідження проблем розвитку інновацій наведено у працях відомих вітчизняних та зарубіжних вчених: Ethan Cramer-Flood [1], П. Соколенко [2], C.O. Єрмак [3], Susan Lund, Jacques Bughin [4], Julia Kutsaniuk [5]. Не дивлячись на багату кількість різноманітних досліджень у цій сорері, інноваційні процеси у торгівлі потребують подальшого наукового розгляду.

Постановка завдання. Метою статті $\epsilon$ дослідження впливу інноваційних технологій на торгівлю та виокремлення переваг їх використання.
Виклад основного матеріалу. Одну з найбільших змін, яку зараз переживає наш світ, $\epsilon$ прогресивний розвиток онлайн та фрізичної торгівлі. Особливо популярною стала електронна комерція через поширення пандемії. Стрімкий розвиток web- та інтернет-технологій сприяють нарощенню світових масштабів онлайн-торгівлі та поступового становленню такого виду продажу як окремої галузі економіки.

Продажі в Азійсько-Тихоокенському регіоні та Північній Америці суттєво впливають на загальні глобальні показники продажів. Особливо значущим $є$ Азійський регіон через те, що він забезпечує близько $50 \%$ усіх цифрових продажів.

У теперішній час спостерігається збільшення обсягу онлайн-торгівлі України. Наприклад, з рис.2, видно, що обсяг у 2020 році збільшився у 2 рази порівняно $з 2017$ роком.

Серед загальної кількості обстежених оптових торговельних підприємств, крім торгівлі автотранспортними засобами та мотоциклами в 2016-2018 pp. 30,1 \% були інноваційно активними, в 2018-2020 рр. - лише $4,2 \%$. Загалом, оптова торгівля $€$ сприйнятливою до впровадження інноваційних технологій. Завдяки їх використанню можливе своєчасне поповнення складів, оптимізація зберігання запасів, ефрективна взаємодія 3 постачальниками продукції та ін.

Незважаючи на те, що торгівлю вважають галуззю, яка має невисокий інноваційний потенціал (якщо порівнювати з високотехнологічними підприємствами), на сучасному етапі її розвитку з цим твердженням можна посперечатися.

У торговельну галузь активно вступають передові технології торгівлі та маркетингу, різноманітні інформаційні, технічні та технологічні інноваційні проекти розвитку, які докорінним чином змінюють традиційне уявлення про торговельний бізнес.

Торгові мережі вважаються найбільш передовим видом торгового бізнесу, тому всі нововведення і технології в роздрібній торгівлі роз- 


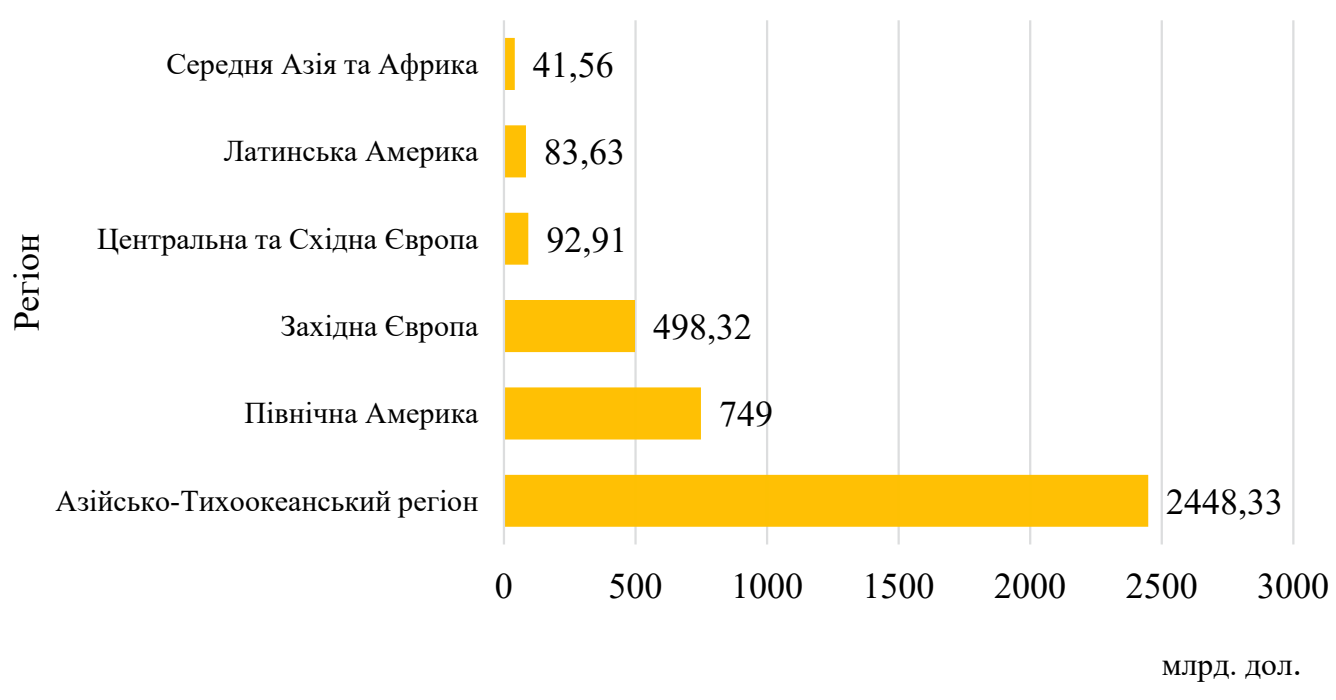

Рис. 1. Обсяги продажів на ринку електронної у світі, 2020 р.

Джерело: [1]



Рис. 2. Обсяг онлайн-торгівлі в Україні, млрд

Джерело: [2]

Кількість інноваційно активних підприємств в оптовій торгівлі,

Таблиця 1 крім торгівлі автотранспортними засобами та мотоциклами, 2016-2018 рр., 2018-2020 рр.

\begin{tabular}{|c|c|c|c|c|}
\hline & \multicolumn{2}{|c|}{$\begin{array}{c}\text { Кількість інноваційно } \\
\text { активних підприємств, } \\
\text { одиниць }\end{array}$} & $\begin{array}{c}\text { Частка кількості інноваційно } \\
\text { активних підприємств у загальній } \\
\text { кількості підприємств, \% }\end{array}$ \\
\hline $\begin{array}{c}\text { Оптова торгівля, } \\
\text { крім торгівлі }\end{array}$ & $\mathbf{2 0 1 6 - 2 0 1 8}$ & $\mathbf{2 0 1 8 - 2 0 2 0}$ & $\mathbf{2 0 1 6 - 2 0 1 8}$ & $\mathbf{2 0 1 8 - 2 0 2 0}$ \\
\cline { 2 - 5 } $\begin{array}{c}\text { автотранспортними } \\
\text { засобами та } \\
\text { мотоциклами }\end{array}$ & 2174 & 300 & 30,1 & 4,2 \\
\hline
\end{tabular}

Джерело: [3] 
робляються і впроваджуються в основному саме на цих підприємствах.

Виходячи 3 того, що інновація - це нововведення, нова або вдосконалена продукція або технологія, отримана в результаті інноваційного процесу, найважливішою її складовою на торговельних підприємствах $є$ вдосконалення технології торгівлі, яка являє собою сукупність робіт, що забезпечують реалізацію торгового процесу найбільш раціональними способами відповідно до конкретних господарських умов [4].

Історія торгівлі відображає безперервний марш нових технологічних інновацій. Наприклад, після Другої промислової революції поява пароплавів та залізниць змінила економіку транскордонної торгівлі. Аналогічно цифрова революція 1990-х і початку 2000-х років дозволила компаніям взаємодіяти 3 віддаленими постачальниками та клієнтами. Глобальні виробничо-збутові ланцюжки існували і до Інтернету, але Інтернет ще більше сприяв фррагментації та осршорингу виробництва за рахунок значного покращення координації та витрат на зв'язок. Коли Китай та інші країни, що розвиваються, почали брати участь у цих виробничих мережах спеціалізованих постачальників і складальних підприємств, торгові потоки різко зросли і розширилися по всьому світу [5].

Сьогодні технології наступного покоління знову змінять торгові потоки та глобальні виробничо-збутові ланцюжки. Але на відміну від попередньої революції в галузі ІКТ, ці інновації матимуть різноманітніший і комплексніший вплив на торгівлю в наступні роки. Деякі досягнення, такі як цифррові платформи, блокчейн та Інтернет речей, продовжуватимуть знижувати транзакційні та логістичні витрати, тим самим підживлюючи торгівлю. Але інші технології можуть зменшити торгові потоки за рахунок зміни економіки та розташування виробництва, а також перетворення фрактичного змісту того, що купується та продається за кордоном [5].

Поширення технологій автоматизації та штучного інтелекту передбачає, що у багатьох галузях різко зміниться значення капіталу порівняно з робочою силою. Зростання впровадження автоматизації та штучного інтелекту у виробництві знижує важливість витрат на робочу силу та робить інші фрактори, такі як близькість до споживчих ринків, доступ до ресурсів, квалісрікація персоналу та якість інфрраструктури, більш важливими.

Автоматизація вплине й на торгівлю послугами. Багато колл-центрів і служб підтримки вже «укомплектовані» віртуальними агентами, які додають можливості обробки природної мови і починають виконувати ширше коло завдань. Це змушує деякі компанії автоматизувати підтримку клієнтів та допоміжні послуги, а не переводити їх у осршоринг. Ця тенденція може скоротити світовий ринок аутсорсингу бізнес-процесів 3 оборотом 160 мільярдів доларів, який зараз є одним 3 секторів послуг, що найбільш активно торгуються.

Доцільно виділити декілька видів загальних інновацій:

1. Покрокові інновації - це інновації, які послідовно впливають на умови споживачів. Як правило, вони мають малий вплив на технологічну еволюцію. Прикладом таких інновацій є поступова зміна проходів у торговельних залах, а саме їх збільшення, задля комфорту пересування у магазині.

2. Технічні інновації - це незначні зміни, наприклад, зручні упаковки виробників.

3. Соціальні інновації - це зміни технологій під час чуттєвої еволюції звичок покупців. Наприклад, доставка продуктів, різні варіанти способів оплати (у розстрочку, кредит), наявність кас самообслуговування та безконтактної оплати тощо.

4. Революційні інновації-значні зміни, коли старі технології змінюються на нові. Наприклад, впровадження електронного обміну даними, програми для управління ресурсами компанії.

5. Локальні інновації - зміни, які відбуваються всередині окремого сегмента та не змінюють технології. Вони призводять до руйнування комерційних відносин. Наприклад, створення власних торгових марок та розміщення їх на стелажах замість продукції відомих брендів.

6. Архітектурні інновації - це зміни, які відбуваються в технологіях складування товарів та представлення їх у торговельних залах.

Щодо детальних інновацій у сфері роздрібної торгівлі, то великих обертів зараз набирають такі технології:

1. Доповнена реальність. Бренд IKEA дає покупцям можливість за допомогою спеціального додатка попередньо оцінити зовнішній вигляд меблів і розмістити їх у своєму будинку перед покупкою. Ідея, яка позбавила багатьох від розчарувань очікування/реальність. Також американське кафре Kitchencray запустило маску в Instagram, яка дозволяє побачити замовлену страву на столі ще до того, як офріціант її принесе. Але цього їм здалося недостатньо - згодом до кожної страви було додано відео з процесом його приготування [6]. 
2. SmartCart. Розумний візок відкриває для покупців такі можливості як навігація, перегляд рецептів та список необхідних складників для обраної страви, а також повну інфрормацію про продукт. Ще SmartCart сканує ваші товари та підбиває суму покупок. Мало того, клієнти магазинів можуть встановлювати свій фрінансовий ліміт, і візок сповістить, коли сума покупок наближатиметься до цієї цисрри [6].

3. Роботи. Вони допомагають власникам ритейл бізнесу на етапі сортування товару на складах. В магазині ж вони взаємодіють 3 покупцями та менеджментом, оскільки в їхні "обов'язки" входить моніторинг товару на полицях, доставка необхідних продуктів клієнтам, а також збір та аналіз даних. Надалі ця інфрормація обробляється для оптимізації бізнес-процесів. Щобільше, роботи можуть давати відповіді на запитання клієнтів різними мовами, а також показати шлях до необхідної полиці [6].

4. Технологія NFC. Також ми бачимо тенденцію зростання використання технологією NFC (англ. Near Field Communication, комунікація ближнього поля), що можна розшифррувати як бездротовий зв'язок на коротких відстанях отримали максимальне поширення в якості технології для здійснення безконтактних платежів. За принципом дії NFC походить на технології Bluetooth i RFID, однак у порівнянні $з$ ними володіє цілим рядом важливих переваг: більш високою швидкістю і більшою безпекою, ніж Bluetooth, і більш широкими фуункціональними можливостями, ніж RFID. Можна використовувати смарт-карту з вбудованим NFC чіпом як проїзний у громадському транспорті, як платіжну карту в установах роздрібної торгівлі, як «розумну» візитку, як безконтактну картку-ключ або як перепуску на підприємство [4].

Очікується, що мітки NFC демонструватимуть найвище зростання за прогнозований період.

5. Електронні цінники. Електронні цінники сьогодні тільки починають поширюватися в магазинах самообслуговування. Замість того, щоб персоналу майже кожен день роздруковувати і переставляти паперові цінники, вітрини оснащуються електронними пристроями, де інорормацію про товари та їх вартості можна міняти натисненням однієї кнопки. Електронні цінники по радіоканалу з'єднуються з безпровідними точками доступу і з них отримують необхідні дані. При зміні вартості продукції співробітник магазина вносить зміну до бази даних закупівельних цін. Ціна продажу автоматично фрормується в тому ж програмному забезпеченні [4].

6. Надолонні каси. Новим інструментом в конкурентній боротьбі представників торговельних підприємств за покупця стали надолонні каси. Вони є доповненням до касового апарату, яке вимагає зв'язку з основним пристроєм для друку чека і прийому грошей за покупки. Основним завданням нововведення $€$ оптимізація часу, проведеного покупцем у торговому залі, i

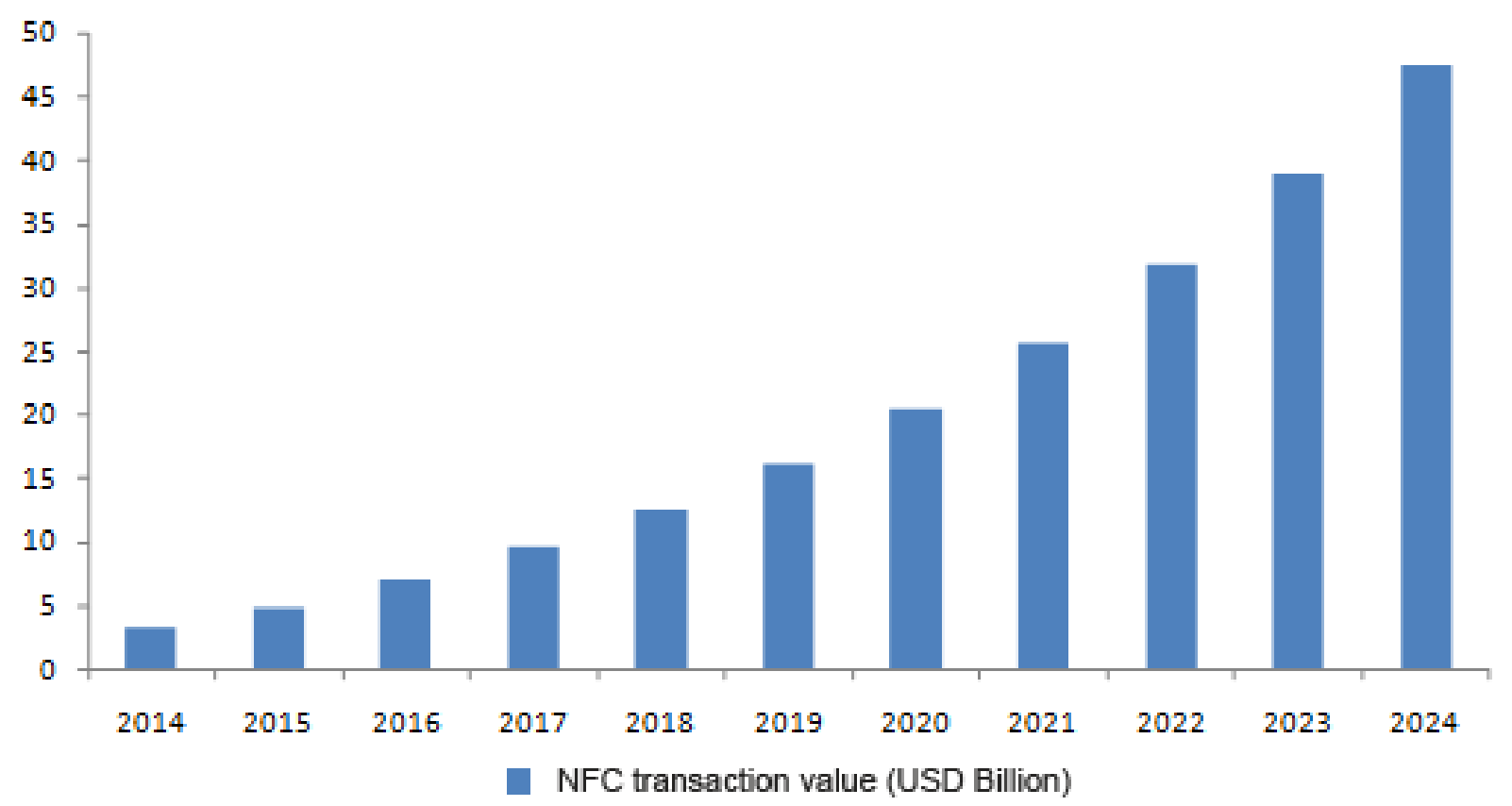

Рис. 3. Об'єм світового ринку NFC, 2014-2024 pp. 
мінімізація черг. Схема роботи з надолонними касами виглядає приблизно так: продавці-консультанти приймають замовлення у покупців прямо в торговому залі, уточнюють наявність товару і повідомляють його вартість. Після того як покупець підтверджує покупку, замовлення по бездротовому зв'язку надходить на касу. Поки продавець-консультант допомагає його зібрати, касир пробиває чек [4].

7. Концепція SoLoMo. Головною новинкою останніх років, що пропонує використання мобільних та інтернет-технологій для просування торгових точок $€$ так звана концепція SoLoMo (з англ. Social - соціальний, Local локальний і Mobile - мобільний). Це поєднання соціальної мережі, геолокації і мобільних платорорм. Мобільні додатки - основний приклад технологій у фрорматі SoLoMo. Завдяки смартфрону, або планшетному комп'ютеру, подібні програми завжди під рукою. Соціальна складова полягає в постійному контакті з дру- зями (за допомогою твітів, або фоотографії в Instagram покупець може негайно поділитися зі своїми друзями цікавими подіями, або новинами 3 магазину. Розповісти їм про знижки та акції, передати своє враження). Геолокаційні сервіси дозволяють у режимі реального часу відслідковувати торгові точки, що знаходяться поблизу, в якій країні і місті покупець би не перебував. І все це - за допомогою мобільного інтернету. Дані технології вже настільки міцно увійшли в сучасне життя і тільки зміцнюють свої позиції, так що власникам роздрібних точок стає складно ігнорувати цю тенденцію, тому інструменти SoLoMo дозволяють роздрібному підприємству витримати активну конкуренцію [4]. Таким чином представлені торгово-технологічні інновації можна згрупувати у таблиці і виділити їх основні переваги.

В таблиці наведені переваги та ризики кожної інновації. Також за 10-ти бальною шкалою представлено на скільки сильно ці ризики

Таблиця 2

\section{Переваги та ризики застосування торговельними підприємствами торгово-технологічних інновацій}

\begin{tabular}{|c|c|c|}
\hline Вид інновації & Переваги & Ризики \\
\hline $\begin{array}{l}\text { Доповнена } \\
\text { реальність }\end{array}$ & $\begin{array}{l}\text { - відсутність розчарувань від } \\
\text { очікування/реальність; } \\
\text { - отримання більшої інсрормації про } \\
\text { продукт на стадії вибору; } \\
\text { - збільшення кількості реалізованих } \\
\text { продуктів; } \\
\text { - можливість зайняти клієнта, поки він } \\
\text { чекає на своє замовлення. } \\
\end{array}$ & $\begin{array}{l}\text { Можлива дезорієнтація, так як } \\
\text { технологія безпосередньо впливає } \\
\text { на сприйняття мозком того, що } \\
\text { відбувається навколо. Віртуальна } \\
\text { реальність може активізувати } \\
\text { морську хворобу, фобобії, властиві } \\
\text { людині. (Вплив } 4 \text { б.) }\end{array}$ \\
\hline Роботи & $\begin{array}{l}\text { - збільшення швидкості обробки } \\
\text { товарів; } \\
\text { - зменшення витрат на робочу силу; } \\
\text { - підвищення престижу магазину. } \\
\end{array}$ & $\begin{array}{l}\text { Високовартісний ремонт у разі } \\
\text { поломки. (Вплив } 8 \text { б.) }\end{array}$ \\
\hline NFC & $\begin{array}{l}\text { - зручність та швидкість оплати; } \\
\text { - надійність; } \\
\text { - зменшення часу продажу і покупки. }\end{array}$ & $\begin{array}{l}\text { Невеликий радіус дії сигналу. } \\
\text { (Вплив } 4 \text { б.) }\end{array}$ \\
\hline $\begin{array}{l}\text { Електронні } \\
\text { цінники }\end{array}$ & $\begin{array}{l}\text { - зменшення витрат паперу; } \\
\text { - синхронізація ціни товару на полиці і } \\
\text { на касі; } \\
\text { - підвищення іміджу магазину. } \\
\end{array}$ & $\begin{array}{l}\text { Єдиним серйозним недоліком для } \\
\text { деяких торгових точок може стати } \\
\text { вартість їх впровадження: покупка } \\
\text { обладнання, монтаж. (Вплив } 8 \text { б.) } \\
\end{array}$ \\
\hline $\begin{array}{l}\text { Надолонні } \\
\text { каси }\end{array}$ & $\begin{array}{l}\text { - зменшення часу очікування в черзі; } \\
\text { - ознайомлення з вартістю чеку } \\
\text { заздалегідь. }\end{array}$ & $\begin{array}{l}\text { Продавець може не встигати } \\
\text { обслуговувати усіх охочих в залі. } \\
\text { (Вплив } 7 \text { б.) }\end{array}$ \\
\hline SmartCart & $\begin{array}{l}\text { - контроль своїх фрінансів; } \\
\text { - отримання інфрормації про продукт на } \\
\text { стадії вибору. }\end{array}$ & $\begin{array}{l}\text { Високовартісне впровадження. } \\
\text { (Вплив } 9 \text { б.) }\end{array}$ \\
\hline $\begin{array}{l}\text { Концепція } \\
\text { SoLoMo }\end{array}$ & $\begin{array}{l}\text { - швидкість роботи; } \\
\text { - доступність офрлайн; } \\
\text { - підвищення престижу бренду. }\end{array}$ & $\begin{array}{l}\text { Малий відсоток користування цією } \\
\text { концепцією старшого покоління. } \\
\text { (Вплив } 8 \text { б.) } \\
\text { Деякі фрункції доступні офрлайн, } \\
\text { але переважна більшість потребує } \\
\text { Інтернету. (Вплив 9 б.) }\end{array}$ \\
\hline
\end{tabular}

Джерело: сорормовано авторами на основі $[4 ; 6]$ 
можуть вплинути (1 бал - майже відсутній вплив, 10 балів - значний вплив). Можна зробити висновок, що усі наведені інновації потребують значних коштів для їх впровадження, особливо для роботів, електронних цінників та SmartCart. Також старше покоління поки що не готове до концепції SoLoMo, так як більшість 3 них не користуються смартфронами та не мають доступу до Інтернету. Ще ризиком, на який варто звертати увагу, це високовартісний ремонт у разі поломки технології. Але тим не менш, ці технології запроваджуються швидкими темпами та торгові точки намагаються зменшити ці ризики.

Майбутнє роздрібної торгівлі вже починається, а саме [8]:

- відбувається перебудування офрлайнточок (торгові площі й вітрини перетворюються на місця для виконання онлайн-замовлень. Це допомагає стати мобільнішими, а також розв'язати проблему з оплатою оренди й технічного забезпечення). Компанія Apple уже використовує роздрібні магазини для обробки онлайн-замовлень. Хоч цей крок був зроблений до всесвітньої пандемії, зараз це допомагає їй утримувати лідерські позиції;

- альтернативні формати традиційного ритейлу (електронна комерція набирає обертів, але найближчими роками фрізичні магазини не зникнуть. Що точно буде - це нові концепції та фрормати звичних торгових майданчиків). Вдалий приклад - Walmart. Американська мережа оголосила про транссрормацію понад двохсот суперцентрів на магазини, які, скоріше, будуть нагадувати аеропорти. Більше вільного простору, більш помітні вивіски, безконтактні каси й багато іншого. Поєднання фрізичних магазинів і онлайн-платорорм створить гібридну модель ритейлу. Магазини нового фрормату дадуть змогу покупцям спочатку випробувати товар, а потім здійснити онлайн-замовлення. Гарний приклад - Canada Goose 3 арктичною кімнатою, де компанія відтворила реальні умови зими за полярним колом;

- онлайн-замовлення товарів та їх доставка на піку своєї актуальності та у майбутньому люди вже не уявляють своє життя без цього.

Отже, можна зробити висновок, що інноваційні технології значно полегшують наше життя та змінюють торгівлю в автоматизований напрям. Роздрібні магазини стають більш комфортними для покупців: автоматизовані каси, цінники, візки, роботи. А впровадження онлайнзамовлень в рази збільшило кількість продажів, тому що зараз, у час пандемії, люди бояться та не хочуть виходити за товарами в офрлайнточки. За цими та іншими інноваціями була сорормована актуальна тема наукової роботи.

Висновки та перспективи подальших досліджень. У статті розглянуто торгово-технологічні інновації, впровадження яких має цілу низку переваг: розширення асортименту продукції, підвищення якості обслуговування клієнтів та підвищення іміджу окремих магазинів та брендів, підвищення продуктивності праці, миттєве отримання інорормації про кількість продукції у торговельному залі, позбавлення клієнтів від розчарувань очікування/реальність тощо. Також наявні і ризики використання цих інновацій: високовартісне впровадження та ремонт, малий відсоток використання старшим поколінням, постійна доступність до Інтернетмережі. Оцінено вплив технологій на майбутнє торгівлі та визначено, що автоматизація та зростання штучного інтелекту змінюють торгові потоки та визначальними факторами стають кваліфрікація робочої сили, якість інфрраструктури та доступ до ресурсів.

\section{СПИСОК ВИКОРИСТАНИХ ДЖЕРЕЛ:}

1. Emarketer: Global Ecommerce 2020. URL: https://www.emarketer.com/content/global-ecommerce-2020

2. Web-machine. URL: https://www.web-mashina.com/web-blog/ecommerce-prognoz-elektronnoi-kommerciiukrainy-2017-2018

3. Офіційний сайт Державної служби статистики. Наука, технології та інновації. Інноваційна діяльність підприємств. URL: http://www.ukrstat.gov.ua/operativ/menu/menu_u/ni.htm

4. Єрмак С. О. Торгово-технологічні інновації в торгівлі на сучасному етапі розвитку України. Есрективна економіка. 2014. № 11.

5. Next-generation technologies and the future of trade. URL: https://voxeu.org/article/next-generationtechnologies-and-future-trade

6. Інноваційні тренди роздрібної торгівлі у 2019 році. URL: https://blog.bvblogic.com/uk/innovaciyni-trendyrozdribnoyi-torhivli-u-2019-roci/

7. The exponential growth of mobile internet application and advancement of $3 G$ and $4 G$ networks is anticipated to drive the market. URL: https://www.grandviewresearch.com/industry-analysis/near-field-communication-nfc-market

8. Майбутнє роздрібної торгівлі. URL: https://www.ustor.com.ua/ 


\section{REFERENCES:}

1. Emarketer: Global Ecommerce 2020. Retrieved from: https://www.emarketer.com/content/global-ecommerce-2020

2. Web-machine. Retrieved from: https://www.web-mashina.com/web-blog/ecommerce-prognoz-elektronnoi-kommercii-ukrainy-2017-2018

3. Official site of the State Statistics Service of Ukraine. Retrieved from: http://www.ukrstat.gov.ua/operativ/ menu/menu_u/ni.htm (in Ukrainian)

4. Yermak S.O. (2014) Trade and technological innovation in trade at the present stage of development of Ukraine Efektyvna ekonomika, 11. (in Ukrainian)

5. Next-generation technologies and the future of trade. Retrieved from: https://voxeu.org/article/next-generation-technologies-and-future-trade

6. Innovative retail trends in 2019. Retrieved from: https://blog.bvblogic.com/uk/innovaciyni-trendy-rozdribnoyitorhivli-u-2019-roci/ (in Ukrainian)

7. The exponential growth of mobile internet application and advancement of $3 \mathrm{G}$ and $4 \mathrm{G}$ networks is anticipated to drive the market. Retrieved from: https://www.grandviewresearch.com/industry-analysis/near-field-communication-nfc-market

8. The future of retail. Retrieved from: https://www.ustor.com.ua/ (in Ukrainian) 